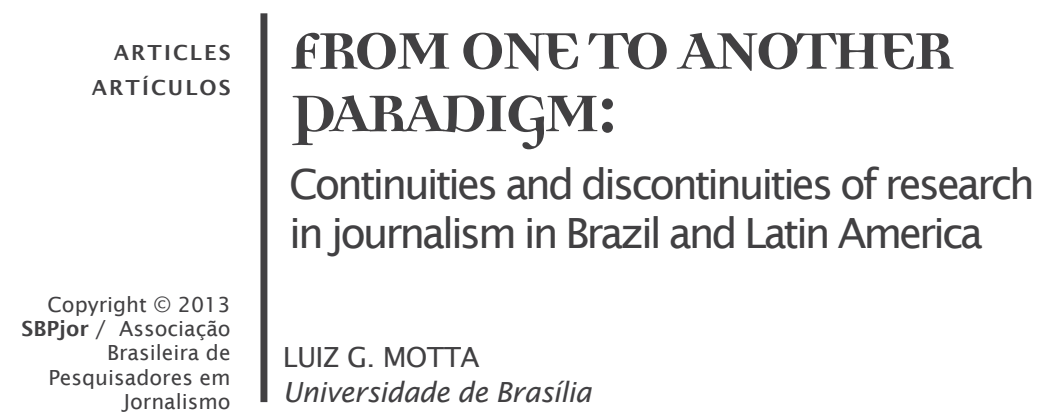

ABSTRACT - The article makes a counterpoint between the critical paradigm, actionoriented, hegemonic in the second half of the last century, and the paradigm of scientific purity and of current theoretical chastity, which requires a distancing between subject and object. The aim is to identify continuities and discontinuities of research in journalism and communication. The author does not make a choice either recommendations, but warns about the inevitably historical aspect of social theories, endorses E. Morin's anthropoethics, his holistic-humanitarian paradigm, and the proposal of Sousa Santos to understand science as a social practice of knowledge in constant dialogue with the world. Keywords: Research in communication and journalism. Conceptual clashes. Social sciences. Paradigms. Theories.

\title{
DE UM A OUTRO PARADIGMA: Continuidades e descontinuidades da pesquisa em jornalismo no Brasil e América Latina
}

RESUMO - O artigo faz um contraponto entre o paradigma crítico, orientado para a ação, hegemônico na segunda metade do século passado, e o paradigma da pureza científica e da castidade teórica atual, que exige um distanciamento sujeito/objeto. O objetivo é identificar continuidades e descontinuidades da pesquisa em jornalismo e comunicação. O autor não faz uma opção, nem apresenta recomendações, mas adverte para o caráter inevitavelmente histórico das teorias sociais, endossa a antropo-ética de E. Morin, seu paradigma holístico-humanitário, e a proposta de Sousa Santos de compreender a ciência enquanto uma prática social de conhecimento em permanente diálogo com o mundo.

Palavras-chave: Pesquisa em comunicação e jornalismo. Confrontos conceituais. Ciências sociais. Paradigmas. Teorias.

\section{DE UN PARADIGMA A OTRO: continuidades y discontinuidades de la investig- ación en periodismo en Brasil y América Latina}

RESUMEN - El artículo plantea un contrapunto entre el paradigma crítico, orientado a la acción, hegemónico en la segunda mitad del siglo pasado, y el paradigma actual de la pureza científica y la castidad teórica, que exige un distanciamiento sujeto/ objeto. El propósito es identificar continuidades y discontinuidades de la investigación en periodismo y comunicación. El autor no elige ninguna opción, ni presenta recomendaciones. No obstante, advierte del carácter inevitablemente histórico de las teorías sociales y apoya la antropoética de E. Morin, su paradigma holístico-humanitario, y la propuesta de Sousa Santos de comprender la ciencia como una práctica social de conocimiento en permanente diálogo con el mundo.

Palabras clave: Investigación en periodismo y comunicación. Confrontaciones conceptuales. Ciencias Sociales. Paradigmas. Teorías. 


\section{PRELIMINARY REMARKS}

It would be a task of immeasurable ambition to attempt to summarize in this paper the myriad of strands adopted by Journalism scholars in Brazil and Latin America. Their diversity is immense, and the enterprise would be herculean and nearly impossible1. For this reason, I shall make use of simplifications which, nonetheless, do not prevent me from making general statements on predominant paradigms in the research in Journalism and Communication in two different periods, after a few observations are made. It will be an attempt to understand the continuities and departures in the history of the research in the field2. Minor exceptions and divergent points will be ignored so I can cause in the reader the response I desire through the narrative I am trying to reconstruct. The purpose is to identify paradigms that set epistemological landmarks in the field, with an evolutionary perspective as my departure point. Such paradigms allow some educated guess at identifying continuities and departures, as well as unfolding new paths for future research.

I shall compare and contrast preeminent paradigms from two different periods in Journalism research in Brazil and Latin America, adopting a position as I do so. My thoughts will be developed at the metatheoretical level - that of the influence from comprehensive paradigms on specific Journalism theories. The discussion will take place, therefore, at the ontological level: aspects of the social world upon which Journalism research should produce its theories, what should be regarded as knowledge of the empirical world, and to what extant theory can provide orientation towards acting upon the world. My personal viewpoint will become clear as the discussion advances.

Let me present my starting point now: every Science or theoretical construction is a field for perspectives, viewpoints and diverging epistemological positions to clash and come into conflict with each other. As a result, no theory or research project can be neutral. There will always be conflicting theories and paradigms behind every academic study. Any theory or any epistemology will encompass conceptual and methodological options previously chosen, which necessarily place each individual project in a certain position among academic and scientific conflicts3. Science, as many other fields, is a space for theories and paradigms to conflict. To ignore this epistemological precept is to withdraw from the conflicts taking place in society and in the scientific world. 
It is from this starting point I choose to develop my line of thought in this paper. I argue that, to adopt a paradigm as opposed to another implies taking an epistemological position that is evaluative, even when the adoption of values is denied by the scholar. If we choose to keep our discussion within the realm of specifically conceptual and methodological issues, I argue, additionally, that the adoption of one paradigm or another will result in theories and studies with a different quality, and a different ability to explain Journalism in a more or less comprehensive way.

At first, I shall present a summary of some of the trends in Journalism and Communication research in Latin America in the second half of the last century. This brief conceptual tour is not an exhaustive description, nor does it intend to include a detailed list of conflicts taking place during this period. It will only highlight certain conceptual clashes in order to demonstrate to what extent the research was involved, at that time, with major political and social issues that affected it, and what issues were, in turn, influenced by the research.

\section{THE CRITICAL PARADIGM}

The first Journalism research in Latin America, in the second half of the last century, was characterized not only by engagement, but also by militancy, by which I mean it was historically developed in connection with some sort of denunciation, ideological non-conformism or proposals of political action or reaction. Unlike what took place in the United States and Europe, where, in the same period, research was dedicated to value asepsis, ideological neutrality and the distance from the object to attain unbiased scientific status, the Latin-American research in Communication (and Journalism) became directly or indirectly involved with political fights, movements against the tyranny of military dictatorships, and the political and ideological hegemony of the cultural industry. Scholars would almost always take the side of those who fought on behalf of democracy, and of movements of cultural and ideological resistance - which they fueled, and from which they took their fuel.

In the second half of the last century, this option was historically inevitable. The region was facing great political instability and undergoing dramatic social changes. Research organizations and social researchers were institutionally involved with social movements with different degrees of participation. The Cuban Revolution and the socialist utopia exerted significant influence on all Latin-American scholarship. Moreover, it was 
consensually known that there was one omnipresent enemy, namely the military dictatorships, which had to be overthrown first of all. Freedom of cathedra and research was part and parcel of all freedom movements as a whole. Thus, Latin America research in Journalism was born with its roots amid the immediate political and social struggles taking place in the period; concepts such as development and underdevelopment, class struggle, cultural imperialism, informative and cultural dependence, etc., now obsolete, indicated epistemological departure points, whenever they did not turn into political and conceptual words.

If the engagement in the Communication research (predominantly in Journalism) in this period displayed a strong political bias, the source of this political commitment could be found in the social relations. Serious economic and social issues remained, regardless of the political regimen, and regardless of the presence or the absence of freedom. Latin America has always been a continent marked by contrasts, where social and economic inequality is explicit. Income concentration rates were (and still are) appalling in the region. In all Latin-American countries, outrageously large sectors of the population live in misery, with experiences of physical and symbolic violence, lack of an acceptable educational system and health care, unemployment, not enough opportunities for generating income, and so on. It would be unethical to conduct research outside the realm of social inequality, when injustice and exclusion were so patent.

Obviously, this political involvement resulted in significant conceptual and epistemological choices. It was certainly due to the need for using research as a political tool that the Marxist critical paradigm became the prevalent episteme in Communication and Journalism studies in the region in the three first decades of the second half of the last century. As in every Marxist study, class struggle, the mode of production and production relations were the starting points, and ideological domination the target. As a result, Communication and class struggle, Communication and ideology, Communication and cultural dependence, and other related expressions were always found in titles of theses, books and papers written in this period of beginnings.

Still in this period, the coming of the French structuralism and the structural analysis (of linguistic and anthropological origin) blended this elegant paradigm with the powerful paradigm of political economy, derived from Marx. In Journalism, the pioneering studies of Armand e Michelle Mattelart (MATTELART; MATTERLART; PICCINI, 1970), published in the Cuardernos de la Realidad Nacional, at the Centro de Estudos de la Realidade Nacional (“CEREN", created and directed by Chilean economist 
Jaques Chonchol during administration of socialist Salvador Allende) on the Chilean newspaper El Mercúrio, and Eliseo Verón's analysis of the Argentinean liberal press in the late 1960's and early 70's are of emblematic importance. Although both authors criticized each other in their papers and books at the time, both adopted a Marxist and structuralistic approach which had a significant influence on Journalism research in the upcoming decades.

Another representative example of the political engagement in the Journalism studies of the period is the conflict between the proposal of quantitative content analysis and the counter-proposal of critical structural-semiological analysis. The structuralistic paradigm (empowered by the political economy) clearly opposed the content analysis (of American and French origin), disseminated in Latin America by the International Center for Superior Communication Studies in Latin America (or, in Portuguese, the "Ciespal", Centro Internacional de Estudos Superiores de Comunicação da América Latina). Structuralists accused content analysis of sticking to the surface of discourse and only studying contents made manifest and not delving into the ideology of journalistic messages from the bourgeois press, which consolidated the dominating culture. The aforementioned study of Verón (1969), for instance, criticized content analysis vehemently, accusing it of being connected with the conservative functionalistic paradigm, although the structuralistic semiological analysis is a tool equally incapable of binding the discourses to the power framework it builds. In these studies, the connection of ideology and power was left to a moment after the analyses themselves, in a more or less arbitrary manner.

As early as the first half of the 1980's, the Latin-American Association for the Investigators of Communication ("ALAIC") was founded, and it represented the high point of the political engagement shared by Latin-American researchers. ALAIC was born as an attempt to unite Communication (and Journalism) researchers in their efforts facing the tyranny of military governments, as research, theses and academic events were filled with political tension. At this point, researchers had realized that it was not enough to denounce the predominant ideology. Rather, it was necessary to face it by whatever means could express what ordinary people demanded, taking into consideration world views different from those found in liberal newspapers.

In its first years, the association, along with the Latin-American researchers, explicitly opposed Latin America's greatest liberal press organization, the Inter-American Press Society (“SIP"), and the organization 
of television and radio broadcast owners, called "AIR" at the time. Thus, the most feasible institutional proposal for making the region's means of communication democratic was to implement national policies of communication and culture, which was an initiative encouraged by UNESCO. In the late 1970's and early 80's this alternative was the main topic discussed by journalists in dozens of meetings, roundtables and publications.

As a radical opponent of the proposal, SIP held a number of meetings with Latin-American newspaper owners, which would subsequently provide newspapers and news programs with their arguments. For this reason, dozens of editorials opposing the proposal were published during the period. Thus, the political and conceptual clashes in Latin-American Communication were reaching the streets and the press, when it came to a moment of explicit tension. The climax of this process was the publication, by UNESCO (1980), of the book Um só mundo, múltiplas vozes (better known as Relatório MacBride)4, which, in 1985, resulted in the American government's taking radical action: it withdrew its financial support to the organization, under the allegation that the proposal for national policies of Communication was harmful to the freedom of press. In this atmosphere of serious political confrontation, it was impossible for aseptic, unbiased, neutral research to prevail.

There were still other foci of tension in the field of Communication where antagonizing paradigms conflicted and researchers were engaged. Encouraged by the Catholic Church (especially the advocates of the theory of liberation) and by grassroots movements, alternative and popular means of communication started to be disseminated: local newspapers, community television stations, workshops for social mobilization, each of which more or less connected with either urban or rural social movements. Paulo Freire's ideas about the consciousness of the masses and practices of liberation and mobilization pervaded most of these popular initiatives5. Mobilizing from the basis through alternative means of communication was a clear conceptual and political clash with diffusionism, an offspring of North-American behaviorist and functionalist paradigms, which had become widespread in rural agencies in the region at the time6.

In this list of local initiatives and grassroots movements, a study later named "participant-research" was born and proliferated. It was a crystal-clear example of social research engagement. This methodological proposal suggests an inter-subjective relationship between the subject 
and the object of the research. In our continent, such inter-subjective relationship attained a rather different character from that of the original participant observation, which has its origins in the anthropological ethnography. Here the adjective "participant" was given the meaning of political action: popular awareness, activism and the mobilization of the very object being studied (the local population) throughout the conduction of the research. Thus, subject and object blended into a single body, which knew itself at the same time as it became known (THIOLLENT, 1980)7.

The researchers' social involvement in the region between the 1960's and the 1990's, in all epistemological strands, was, therefore, fairly intense, if one is reminded that research practices and political ones could not be isolated from one another. It can also be noted by way of an illustration that the aforementioned Mattelart recognized much later that his most widely known and criticized work, How to Read Donald Duck (MATTELART; DORFMAN, 2010), a decidedly political anti-American and anti-imperialistic analysis, was very close to being a politicalcultural manifesto, the typical case from this period of an analysis with pretensions to the status of good scholarship which simultaneously played the role of a political manifesto. This may sound strange today, but it becomes understandable when we bear in mind the political and ideological tension mid-20th-century Latin America was facing.

Way beyond Marxism and structuralism, the feeling of indignation shared by researchers at the time in a region which was politically tyrannical, economically and socially unequal, informatively and culturally dependent, evinced a crying need for research committed with the fight for social justice and more political and academic freedom, i. e., research that is engaged in human emancipation and the ideals of a more just and democratic society - which most Latin-Americans lacked during that period of beginnings. Thus, the social commitment of the first Journalism and Communication studies in Latin America brought with them the search for a better world, alternative views about society, emancipation and human dignity - in short, "extreme humanism".

It is in the field of metatheory, therefore, that we can regard the critical paradigm as the inspiration behind the Journalism and Communication research in Latin America in the second half of the last century, as this brief overview demonstrated. In spite of the diversity, most researchers had as their starting point the division of society into social classes, the sovereign existence of a preeminent class and the asymmetrical relationship of the flows of Communication. This lack 
of economic and political balance enabled researchers to confirm the connections between dominant classes and the ideological apparatus. The real intention of researchers - influenced next by new and old Frankfurters - was the emancipation of subjects facing the forces of oppression8.

A parenthetical note: Among the critical perspectives there were also fierce clashes - always, however, with action as their purpose. For instance, the thoughtful and insightful judgments of Barbero (1998) and Canclini (1983; 1997), inspired by the authors of English cultural studies, opposed the Frankfurter ideas9. English cultural studies (also a critical perspective) showed, in turn, that class domination is not linear. According to this strand, there is no pure dominant (or dominated) ideology, without any contamination from its contrary counterpart; nor can there be absolute domination. The color of ideological dispute is a shade of gray, rather than black or white. In culture, this strand would argue, there is always a fight for hegemony, with advances and retreats depending on the acting forces in each historical situation. One cannot ignore the influence of this strand in the following decades10. The contradictory character of social relations, however, had not pervaded the research in the continent in the middle of the 20th century. This influence would only become pervasive during the late 1980's and early 90's.

I finish my note and turn back to the previous critical paradigm, which provided researchers with an explicit epistemological position, an intellectual activism which resulted in a prescriptive character of theory: it was a power for orienting action. In the AL of this period, Science was not only a place for confrontation; it was part of the political conflict itself; it combined not only the fight for democratization and social justice, but also the resistance of a critical paradigm facing the preeminent paradigms of the first world countries, the behaviorism/functionalism. The subject-object relation was nearly always inter-subjective. Rather than proximity, however, what existed was an ongoing social process of feeding and being fed. To sum up by paraphrasing Paulo Freire, I would say that the critical contribution of the research in history turned its own object - Communication - a "practice of freedom".

\section{THE EPISTEMOLOGICAL QUESTION}

Up to this point, I have outlined the history of Journalism (and Communication) in Brazil and Latin America in the second half of the 
last century. To retrieve paradigms and conflicts representative of this moment of beginnings in a more comprehensive way, however, could be the goal of a more in-depth study than the unpretentious reflection I develop in this work. This will not prevent me from going back to a specific question regarding the conceptual and epistemological legacy of this rich and contradictory period, in order to observe continuities and departures in the Journalism and Communications research in the region. Thus, I pose some disturbing questions.

Did the changes that took place at the turn of the century conceal the academic engagement on behalf of value asepsis and a scientific self-affirmation? Or does the commitment to social changes still remain, ubiquitous in the conceptual and epistemological memories of researchers in the region? Did the achievement of an undeniable economic growth in the Latin-American countries over the last two decades (in this regard unquestionably led by Brazil) make social concerns on the researchers' part unnecessary? Were the balanced income distribution attained by these countries and the social benefits their governments granted enough to dispense with the contributions research can make to public social policies?

In order to contextualize the changes, let us remember, as T. Kuhn (2001) warns us, that a paradigm cannot change through the linear development of a given field of research. The old paradigm is corrected or replaced, simultaneously, by a more or less radical rupture within society, an abrupt and little structured historical event, which a specific field of research will influence and by which it will be influenced. A departure thus takes place in the models and dogmas and a new moment unfolds, preceded and followed by conflict situations, stress and contradictions. Between the attachment to the past and the inevitable change in direction, new tendencies, antagonisms and speculations grapple with each other, until the new paradigm is settled as a new scientific world view. What is, then, the new orientating paradigm of the Journalism and Communication research of the region? Does this new paradigm correspond to the economic and social transformations taking place in the region?

For the deliberate purposes of causing discomfort, I dare to say here that the most meaningful epistemological difference between the research conducted in the previous, troubled period and the one in progress today is the contemporary option of neutral, unbiased research, more distant from society in which it is developed - in short, "more objective and scientific" research. I dare to state that current research 
has made a relatively explicit choice for an unbiased scientific ideal. To carry it out, in my view, it moved away from its object: concrete social relations. Thus, on behalf of an academic self-affirmation, researchers preferred to distance themselves from political and social facts, leaving "activism" to professional politicians, political parties and socially engaged movements.

The statement I have just made is provoking, rather than unquestionable. First, because there are different degrees of social engagement, which change depending on the researcher and the circumstances of his research. There are a range of variations and a number of exceptions. Second, because this statement would make it necessary for systematic, empirical evidence to be produced, which goes beyond the scope of the present paper.

However, when one looks at this overview from a distance, it seems to me that there a choice has been made for research ever more concerned with purity and conceptual cleansing, with a focus on theoretical chastity, methodological elegance and the rigorous control of operational processes. The research that distanced itself from its object became increasingly more preeminent and concerned with causal regularities of conceptual models, which become more relevant than the social commitment as an epistemological starting point.

\section{THE PARADIGMATIC TURN}

In spite of the existence of much more remote roots, which could not possibly be retrieved by such a short analysis, the turn of this historical period took place at some point in the last two decades of the 20th century - and, as early as the beginning of the following century, we found ourselves a new set of paths. The idealism of research as a tool for political advancement was lost between the middle of the 1980's and the early 90's, with the end of dictatorships, the triumph of market capitalism and globalization, which brought them the hegemony of consumer society, disseminated by the media culture and scientificism. It should be further said that the advent of post-modernity marked the end of the great narratives, a rupture in the connection between the account of a certain past and a predictable future, Lyotard's (1998) end of social evolutionism. Did the changes also mean an end to historical evolutionism in Communication (and Journalism) research, the end of a historical participant narrative, which was conscious and socially engaged? 
The change at the turn of the 20th century brought about, therefore, an inevitable transformation in society as a whole, and in Latin-American scholarship. It did not take long before the region left pre-modernity and entered modernity (or post-modernity), if I may adopt Giddens's (2002) terms, which I find appropriate to the purposes of this paper 11 . In his view, new lifestyles devastated unprecedentedly all previous modalities. Departures quickly reached the whole of the surface of the Earth and changed the very nature of institutions like the state-nation and our usual dependence in traditional production processes12. In their specific realms, Giddens says, Social Sciences are parasitic to profane concepts of the world of life, and vice-versa, reconstructing themselves, as much as the very social universe, as a spiral of mutual influences. Such dynamics (dis)anchors social relations from their local contexts of structuring and restructure them in new orders. Thus, researchers - a system of experts - changed, not for personal or professional preferences, but because the world changed and (dis)anchored institutions from their traditional places, imposed new demands, dissolved social evolutionism and historical teleologies, placing in its stead new systems of reliability (a new faith).

This process is not devoid of conflicts and paradoxes, as in every paradigmatic change, corroborating Thomas Kuhn's (2001) ideas. In a changing society, the coexistence of technological sophistication and the incorporation of nations to the global market living side by side with poverty and social exclusion is a paradox. Another paradox, in the conceptual field, is the supremacy of a formal-objectivist model in the Social Sciences, which is simultaneous with a repeated opposition to the rationalist determinism; just as the prevalence of a formal logic is a paradox (i.e., an exhaustive search for uniform patterns of behavior, for immediate relations of cause and effect), simultaneous with a holistic attitude that calls for the creation of free inner space (our subjectivities). Another paradox is the prevalence of a fragmentary and reductionist logic coexistent with a holo-epistemology (or holism), which proposes a dynamic interaction between the whole and its parts (CREMA, 1988; WEIL, 1990; CREMA; BRANDÃO, 1991). In spite of these paradoxes, conflicts and varieties, a "purifying" estrangement on the researcher's part from the "impurities" of the political and social reality seems to have become preeminent in Western Social Sciences.

It would be necessary, then, to delve deeper into the passage from pre-modernity to modernity (or post-modernity) and its consequences, as it was done in the studies of scholars like A. Giddens (2002), Z. Bauman 
(2009), U. Beck (1997) and others, in order to clarify the complexity of this epistemological transition. We must return to the conceptual and epistemological question of continuities and departures between the previous period and the current moment in Journalism research in Brazil and Latin America, which is, in my view, a reflection of this passage to modernity (or post-modernity). This is not a new discussion, nor does it belong to our field alone, but it is important to bring it back to life from time to time in order to identify the unconscious tendencies and risks in in our choices.

Furthermore, there are signs which are subtle, some even visible, that the apology of a "pure" social science and the defense of the autonomy of its mode of production - the competition between scientists and the equality of opportunities for all researchers - conceals what Portuguese sociologist Boaventura de Souza Santos (1989) terms "the industrialization of Science". Thus, the estrangement of the scientific discourse in connection with common sense and the esthetic and political discourses, as he says, deepen the specialization of the scientific community and do not cease to increase its distance from society, making it impossible for the scientist to understand what happens around its ever smaller dwelling place (which he ironically calls Scientiapolis).

It is also interesting to bring into the discussion the significant withdrawal of the sociological-critical paradigm and the advancement of the balance paradigm in our research circle in this transitional moment. The critical paradigm, or conflict paradigm, sees society as a whole, in which different social groups clash in the search for hegemony, which makes it possible for the researcher to take as his departure point the clash between groups, relations based on repression and domination, the meaning of each social object (institutions, discourses, etc.) as a mechanism or strategy in the struggle for power. The balance paradigm, on the contrary, admits that social relationships are essentially harmonious and inequalities are seen as part of a natural process of ongoing social accommodation. Thus, the focus is cast on the transgressions and adjustments of deviant behavior (HAVENS, 1972).

Conflict and balance paradigms are, in turn, two opposite sociological paradigms that represent antagonizing methodological and conceptual pre-options. Hypothetically, if we could classify Journalism studies in the three last decades into these two broad foci, to which side would the scales lean? I pose the following question: to what extant does the prevalent tendency of Journalism research take into consideration current social, economic, political and cultural conflicts as its starting 
point? To what extant would it rather ignore them as irrelevant or little appropriate to conceptual models? To what extant does it regard them as little relevant? To what extant does it choose to leave them aside on behalf of the elegance of methodological models, or on behalf of intellectual purity?

I believe it would not be much of an error to say that the ideal of research which is more elegant conceptually and methodologically (from the formal perspective) and less contaminated by the spirit, by politics and by the heart seems to become the prevalent model of Journalist and Communication research (as happened in other fields of Social Sciences) in the transition that took place at the turn of the century; research that increasingly distances itself from the human being, from the community, from society; research that shatters knowledge into ever smaller particles, that seem more and more disconnected from the social whole13; an epistemological problem identified and criticized by E. Morin (1999, p. 48):

\begin{abstract}
It is impossible to conceive the complexity of man through the disjunctive thought, which conceives our humanity in an insular way, out of the surrounding cosmos, out of the physical matter and out of the spirit of which we are made, as well as through the reducing thought that limits the human unity to a merely bioanatomical substrate. Human Sciences are themselves fragmented and pigeonholed. Thus, the human complexity becomes invisible and man vanishes as a trace in the sand... Paradoxically, one watches the ignorance of the whole become ever grimmer, while the knowledge of the parts moves forward.
\end{abstract}

A new paradigm, he warns us, may elucidate and blind us at the same time; it may unfold and simultaneously conceal the truth.

\title{
A NEW PARADIGM?
}

In the conclusion of this paper, I do not intend to laud or condemn personal or epistemological options, nor do I have the pretension to make formal recommendations of thematic or methodological nature about what Journalism research should be. Neither do I believe that every researcher should make rational, explicit and definitive choices of one paradigm or another before putting into practice each individual project. I cannot enter here the realm of Philosophy of Science or the discussion about which paradigm has the greatest clarifying power or the greatest feasibility in its application on the empirical reality of Brazil and Latin America. For those who wish to have another look at these topics, I recommend the confrontation promoted by other scholars (HAVENS, 1974; MILLER, 2002), since this comparison goes beyond the purposes 
of this paper.

However, I do feel tempted to endorse some of the crucial notions suggested by Edgar Morin (2005), which must be taken into account by researchers in their continuous epistemological options. I shall invert the seven notions indicated by the scholar and I shall bring to the fore of his anthropoethics (the ethics of humankind) the greatest challenge of today's world - to build notions and social practices without one's failing to respect fundamental freedoms. Anthropoethics, Morin teaches us, encompasses the hope for completeness of humankind as a planet-wide conscience and a civil sense. It further encompasses the aspiration and the will, but also places its bet on the uncertain: "It is the individual conscience beyond individuality." A threefold ethics, as the author argues, conscious of the fact that the human being is at once an individual, a part of society, and a part of its species. Thus, he says, "the truly human development should include the set of individual autonomies, of collaborations and of the consciousness of belonging to humankind." With this principle as a start, Morin concludes, the ultimate ethical-political goals are outlined: "to establish a relationship of mutual control between society and the individual for democracy" (MORIN, 2005, p. 17).

Thus, we shall have to consider, as Morin warns us, the determinisms derived from the beliefs taken as the dogmas of a field, which exert a normalizing force of taboos, prohibitions, rigidities, hindrances: "the dominant doctrines and ideologies equally avail themselves of the imperative force which brings evidence to the convinced and [likewise avail themselves] of the coercive force that arouses the fear which in others is capable of inhibiting." He goes on: "the beliefs are not only products of the mind, but also mental beings that have life and power. In this way, they can take possession of us" (MORIN, 2005, p. 27). This is why, he concludes, we need to civilize our theories, develop new open, rational, critical, self-critical, theories, which are capable of selfreformulation.

Even more appropriate than a previous epistemological attitude, what concerns us here is the search for orienting paradigms of theory and research, master conceptions that select and subdue the operational concept of analyses. As observed by Edgar Morin, the paradigmatic level, hidden under the logic conducting the study, is that of the beginnings which select the ideas, which in turn will be integrated with the theory and the development of the empirical analysis. Moreover, the paradigmatic level performs the logical operationalization of research, 
assigns fundamental categories and their use in empirical investigation. Thus, Morin summarizes, "individuals learn, think and act according to paradigms culturally inscribed on them... The paradigm founds crucial relationships that make up axioms, determines concepts, rules over discourses and theories" (MORIN, 2005, p. 25-26)14. But beware: our systems of ideas, theories, and doctrines are subject to error and also protect the error and the illusions. They resist ideas that are not convenient to them or that they cannot assimilate. In this manner, theories resist the aggression of antagonizing theories and opposing arguments. Even scientific theories (which should presumably accept refutations) may show such resistance.

The proposal of building notions and social practices respecting freedoms takes me back to the concept of "development as freedom", as defined by Nobel-winning Indian economist Amartya Sen (2009), now a professor at the University of Harvard. Sen's ideas, in my view, are relevant as parameters and inspiration for the construction of a holistic and humanitarian paradigm, inspiring to the Social Sciences of this new millennium and to a multidisciplinary Communication and Journalism theory in particular. Sen proposes freedom as an end of the process of human development, bringing back what was formerly regarded as the goal of development (an increased income, the access to health care and education, technological advancements, civil rights and other social indicators) as mere means for restricting opportunities. He argues that they should be destroyed in order for one to reach the supreme good, the most comprehensive one of all: human freedom 15.

I refer here to the ideas of Amartya Sen not only because they regard freedom as an end of the process of social development and corroborate, in my view, Edgar Morin's ideas, but also because they take us back to the risks of abandoning social relations as the beginning and the end of social theories and studies. Despite the unprecedented increase of global opulence and the advancement of democratic governments, he remarks, the world refuses to grant elementary freedoms to an enormous number of people. Thus, we are reminded that economic growth, the conquest of a better general well-being and the increase of individual freedoms of the last decades have not eliminated the inequalities, the exclusion, the alienation and the cultural dependence.

The Brazilian example illustrates this contradiction rather well: we are currently the world's sixth economy, but out our HDI (Human Development Index) ranks 84th. Our country's inequality and social exclusion provides us with a good illustration of the paradox: on one 
side, the enviable economic growth, that fills us with pride; on the other, the persistence of poverty, misery, urban violence, lack of good transportation, underserved schools and health care stations and so many other kinds of privation that limit the freedom of people and communities and that bring us shame. Thus, if we have sophisticated aeronautic industry, enviable technology for elections, if we have developed bi-fuel motors and ethanol technology, and so many other advancements reproduced the world over, we still have, on the other hand, a high child mortality rate, a life expectancy rate lower than that of much poorer countries, among other shameful indicators. How can this be explained? How can one not feel outraged before this situation? How should one keep ignoring these facts as reference for our research?

Our theory, our paradigms, our categories of analysis should not, in my view, ignore such social contradictions as departure points, without alienating themselves from them on behalf of research that is pure, scientifically skeptic and distant, with false objectivist accuracy. As a result, to insist in "scientific asepsis" to justify a type of research and theory that is satisfied by self-explanatory beauty is an act of cynicism, alienation and academic arrogance. As Communication researchers, we must not turn a blind eye to the barbarism disseminated in our cultural industry. We do not have the right to let our belts hang loose or refrain from being outraged before an atrocious reality, unsettling and oppressive towards basic human freedoms.

By saying this, I do not mean that academic research should be at the service of immediate social demands, or submit to the requests of public policies. In reality, scientific knowledge must take a certain distance from history, be relatively autonomous in its choices, and develop autonomous theories. With this perspective in mind, I do not make any claims, nostalgically, for a greater clarifying power for researches of previous decades. They do not necessarily have greater clarifying power or heuristic value because they flourished out of social and political soil. It is not a matter of coming back or copying the past. The secularization of customs and the development of a new scientific spirit brought about different demands from those in the previous centuries. The recovery of the sources of Latin-American studies in this paper should merely serve for clarifying the inevitably historical character of social theories, theories of Communications and, in particular, Journalism, as well as for testifying that History moves on and contemporary theories have an equally historical character (which will maybe be more explicit when seen from the future). 
The current moment of research is a different one, and the challenges are of another nature. Scientific knowledge requires a rigorous path; it demands strict criticism of the procedures of each project, a permanent control of subjectivities. More than ever, it requires us to avoid dogmatisms. If compared to the past, role-models developed by Communication and Journalism research have a more comprehensive clarifying and predictive power. The understanding of social phenomena grew sophisticated, more factual and accurate, in such a way that one does not repeat the dogmatic axiom according to which the dominant ideology is a devastating, imposing force. Rather appropriately, the apprehension of cultural dynamics started to consider opposing forces in an ongoing conflict against each other (MOTTA, 1983)16.

Researchers are much more attentive, careful, systematic, and they are correct. In terms of systematizing and rigor, research has not receded - on the contrary, it has evolved considerably. In its formal aspects, we are much better off than before. As regards thematic issues, as I remarked in another text (MOTTA, 2005), Journalism research has evolved from a cliché, media-centered, simplifying paradigm to a societycentered paradigm, of greater clarifying capability. Media and Journalism are not seen as mere "industries of consciousness" any longer. Therefore, going back and copying the past is no longer a valid option.

As a result, there are risks in adopting a disguise of pseudoneutrality on behalf of a "purer and more modern" type of knowledge. Ethical demands, in my view, remain as the background and offer theories a broader sense, making them more valid as comprehension, explanation and transformation of the social whole. Thus, as far as it is possible in each situation, I argue that research and social theories should leave and return to the social relations of society, which is responsible for their existence, sense and viability. Ethics lies far above morality. Can it be true that we no longer have reasons to feel outraged by a reality of hedonism, fetishes, misfortunes and uncertainties regarding the contemporary Latin-American world? Can it be true that we do no longer need master conceptions inspired by human emancipation and dignity to provide us with the light we need for our field research?

In order to support my point of view, I conclude by quoting once more from the wise words of Sousa Santos (1989, p. 13-14), on the knowledge we have regarding our own Science (which he calls a hermeneutic process), a consciousness necessary to turn it from a distant and immeasurable object compared to our daily lives, into a familiar and close object, capable of communicating its valencies and boundaries. To 
understand Science, he says, is not to found it through dogmas in any of the a priori principles. Rather, he concludes:

[...] one must understand it as a social practice of knowledge, a task that is performed piecemeal through dialogue with the world, and which is ultimately founded on the vicissitudes, oppressions and fights that are part and parcel of it, and of us - regardless of how comfortable or outraged we are... To make understandable what Social Sciences stand for in society, and what they say about society... As a practice of knowledge, Social Sciences turn society into a number of theoretical objects and, in this sense, they objectify society (they turn it into a thing). However, the social element of this knowledge renders this objectification useable and therefore subjectifiable. This happens in the exact same proportion as theoretical objects are transformed into the social objects of the social subjects that may invest in social-scientific knowledge and, therefore, avail itself of it.

I do not deem it necessary to add further information to this short discussion on continuities and departures in the orienting paradigms in Communication and Journalism research in the Latin-American continent. Every researcher must make his own reflections as to what should be taken as valid knowledge of the empirical world and to what extant his theory may serve as orientation for action upon this world.

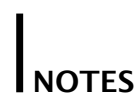

1 I refer those interested in recapitulating summaries to the work of Weber, Bentz e Hohlfeldt (2002), which discusses trends in the research, particularly the paper of C. Berger (2002), in the same collection. Additionally, the collection of C. Lago e M. Benetti (2007) adopts the same approach. I further recommend readers to look at the latest issues of the Brazilian Journalism Research, in which papers from a number of scholars outline systematic descriptions of the latest trends in Journalism research. Dozens of theses and dissertations from graduation programs can be found which present partial summaries of Journalism studies. For a comprehensive overview of major Communication theories (which include Journalism theories), I refer to the work of Katherine Miller (2002).

2 It is difficult to distinguish Communication research from Journalism research in Brazil and Latin America. Although both fields are starting to develop relatively autonomous disciplines, they were often confused with one another during the second half of the last century, and even today they often overlap conceptually. A large number of studies on productive processes, discourses and reception of Journalism, for instance, are regarded as Communication research, even when their empirical object 
is reportage. It is almost impossible to set clear-cut boundaries between the research of autonomous Journalism and that of Communication. In this text, both fields may be confused. I would like to make manifest my awareness of this deadlock, and I ask readers to be mindful of inevitable overlapping areas.

3 I adopt in the present paper the concept of theory as defined by Miller (2002, p. 23), which refers to the concept of metatheory: "A theory is an abstract statement that provides an understanding or explanation of something observed in the social world. A theory functions to answer empirical, conceptual, and practical questions, and the quality of a theory can be assessed... in terms of the answers provided to those questions".

4 French-Irish jurist, journalist and human rights activist Sean MacBride was the chair of the commission. Founder of Amnesty International, he passed away in 1988. Among the Latin-American members, two prominent intellectuals were present: Colombian writer and journalist Gabriel García Marquez and Chilean economist Juan Somavía, thendirector of Latin American Institution for International Studies ("ILET", in Spanish, Instituto Latino-Americano de Estudios Internacionales), which conducted dozens of studies on the continent's informative dependence. Fernando Reyes Matta, renowned scholar from Chile, also a member of the ILET, worked as an advisor.

5 Paulo Freire (1980) reminds us that he did not coin the term "conscientization"; rather, the coinage should be attributed to the Superior Institute for Brazilian Studies (Portuguese: Instituto Superior de Estudos Brasileiros, "ISEB"). He does recognize, however, that what the term refers to matches perfectly the concept of education as a practice of freedom, an act of knowledge which was brought about by a critical proximity with reality: "conscientization requires us to go beyond the spontaneous sphere of reality apprehension and reach a critical sphere where reality happens as a cognizable object and man takes an epistemological position. Conscientization is a reality test. The more one 'un-veils' reality, the deeper reality penetrates into the phenomenal essence of the object... For this very reason conscientization is a historical commitment. It is also historical consciousness: it is a critical insertion into history; requires people to take the role of subjects who make and remake the world" (FREIRE, 1980, p. 26). The definition of Freire's term clarifies how "critical" is to be understood - an an adjective that became popular among researchers and political activists in the region.

6 Once more, Paulo Freire is the inspiration behind the conceptual and political clash. In a paradigmatic essay, Freire (1970) equates the extension activity with the persuasion and domestication of a subject 
(the extensionist) upon an object (the peasant). On the other hand, he dissociates inter-subjectivity from intercommunication in order to replace the extension with a communicative relationship between knowing subjects around a cognizable object: "Every thinking act demands a thinking subject, a thought-of object [...] and the communication between both [...]. Hence the contents of communication is not able to be communicated from one subject to another [...]. Communication, on the contrary, implies unbreakable reciprocity" (FREIRE, 1970, p. 65-67). True communication, he goes on, cannot be found in the mere transference of knowledge from one subject to another, but in the collaborative act of learning: "This is the communication that is established critically" (FREIRE, 1970 , p. 70). Paulo Freire's concept of participant communication influenced researchers in the period profoundly.

7 The "workers' poll" of Michel Thiollent (1980), Marxist in its character, sought to articulate sociological action with the conscientization and mobilization of workers, strengthening the relationship between the political vanguard and the masses. Each item in the questionnaire suggested by this methodology served as didactic stimulus for "freeing" the subjects and arousing in the worker a conscious response over his own political and social situation.

8 To those interested in the influences and the criticism about the ideas of the Frankfurter School, I suggest Mogendorff's (2012) review. In his paper, Mogendorff clarifies how ethics was the main focus in the works of German scholars, in which they criticized the mass production of knowledge. The paper also summarizes the criticism made by some scholars against Frankfurter theories (including Martin-Barbero). I additionally recommend Rudiger (1998).

9 At first, influences came from English Marxists E. O. Thompson (1988) and R. Williams (1981), as well as from Italian Marxist thinker A. Gramsci (2005). Later, S. Hall (1992, 1993, 1997), another exponent of English cultural studies, became a major reference for communication studies in the region.

10 I discussed this influence in my previous paper (Motta, 1983). In this connection, one should recall the dynamic definition of popular cultures of Canclini (1983, to which I subscribe: they are the outcome of an unequal appropriation of the cultural capital in life conditions by means of which there is a conflicting [his highlight] interaction with preeminent sectors).

11 Many scholars would rather say that the moment of paradigmatic transition more or less simultaneous with the last turn of century is, in 
reality, the passage from modernity to post-modernity. Boaventura de Sousa Santos (1989), for instance, in want of a better designation, uses the term "post-modern science" to refer to the Science born after the transition of knowledge forms that took place in this historical moment.

12 I believe that this definition of pre-modern and modern is quite suitable for the Latin-American transition. According to Giddens (2002), in the pre-modern culture, kinship ties, the familiar character of the community, the religious cosmologies and tradition stabilize social bonds and ensure confidence when risks must be taken. In modern societies, personal or sexual relationships, friendship, abstract systems and the orientation for the future become the variables that stabilize these bonds. The passage from one moment to the other, which earlier meant social continuity, causes a feeling of imprisonment in a universe of incomprehensible events, whose ultimate senses are made unreachable.

13 I cannot discuss the specialization of knowledge in depth here. Nicolescu (1999) names this fragmentation of Sciences the disciplinary "bigbang", a movement that multiplied the disciplines, closing them upon themselves. A radical, rationalist movement that understands the world as a machine, whose components can be known individually, as if they were isolated, sealed compartments - a tendency towards reduction that, in his view, makes the complex simple, quantitative and objective, thereby abolishing ambiguities and uncertainties.

14 Morin states that "the paradigm plays a role at once subterranean and sovereign in any theory, doctrine or ideology. The paradigm is unconscious, but pervades the conscious thought, controls it and, in this sense, is also supra-conscious" (MORIN, 2005, p. 26). It is convenient to recall T. Kuhn's (2001) concept of paradigm. In his definition, a paradigm is a scientific model or standard universally acknowledged during a certain period of time, which provides scientific practitioners with model solutions; it also indicates a constellation of beliefs, values, procedures and techniques shared among the members of this community. It is, therefore, much more than a theory, as it generates theories.

15 Sen regards the substantive freedoms of individuals as a basic component of development. In his view, people's ability to lead the lives they find appropriate can be enhanced. This will exert its influence on the direction of public policies and in the ability to participate. Having more freedom, he argues, increases people's potential to take care of themselves and to influence the world. Thus, he places as the focus of his proposition the condition of the subject as an active and autonomous agent (SEN, 2009).

16 In a paper published as early as in 1983 (MOTTA, 1983), I warned readers about the simplification deriving from the Marxist orthodoxy regarding 
the ideological incorporation of subdued classes by the cultural industries. I said, then, that there is no devastating cultural manipulation. All the ideological paraphernalia always comes across concrete historical and social conditions. Nor should theory deify the popular culture that is "pure" or "superior", since it is always pervaded by values from the preeminent culture. On studying cultural practices and representations of a certain social segment, I also said that it was necessary to regard them as reactions to the actions performed by other groups, since the movements organized by a certain group or class will always be carried out through explicit or implicit confrontation with other forces, both at production level and that of everyday life and the exchange of cultural goods.

\section{REFERENCES}

BARBERO, J. M. De los medios a las mediaciones. Bogotá: Ed. Gustavo Gili, 1998.

BAUMAN, Z. Vida líquida. Zahar: Rio de Janeiro, 2009.

BECK, U. In: GIDDENS, A.; BECK, U.; LASH, S. Modernização reflexiva. São Paulo: UNESP, 1997.

BERGER, C. Jornalismo na Comunicação. IN: WEBER, M.; BENTZ, I.; HOLFELD, A. Tensões e objeto da pesquisa em comunicação. Porto Alegre: Sulina, 2002.

CANCLINI, N. G. Consumidores e cidadãos. Rio de Janeiro: UFRJ, 1997.

CANCLINI, N. G. As culturas populares no capitalismo. São Paulo: Brasiliense, 1983.

CREMA, R. Introdução à visão holística. São Paulo: Summus, 1989.

CREMA, R.; BRANDÃO, D. M. S. O novo paradigma holístico. São Paulo: Summus, 1991.

FREIRE, P. Conscientização. São Paulo: Cortez e Moraes, 1980.

FREIRE, P. Extensão ou comunicação? Rio de Janeiro: Paz e terra, 1970.

GIDDENS, A. Consecuencias de la modernidade. Madrid: Alianza, 2002.

GRAMSCI, A. Cadernos do cárcere. Rio de Janeiro: Civilização Brasileira, 2005.

HALL, S. The question of cultural identity. In: HALL, S.; HELD, A. M. Modernity and its future. Cambridge: Polity Press, 1992. p. 274-316.

HALL, S. et al. A produção das notícias. In: TRAQUINA, N. Jornalismo. Lisboa: Vega, 1993.

HALL, S. Cultural representations ad signifying practices. Londres: SAGE, 1997. 
HAVENS, E. Methological issues in the study of developmet, I Sociologia ruralis, v. XII, n. 3-4, p. 252-272, 1972.

KUHN, T. A estrutura das revoluções científicas. São Paulo: Perspectiva, 2001.

LAGO, C.; BENETTI, M. Metodologia de pesquisa em jornalismo. Petrópolis: Vozes, 2007.

LYOTARD, J-F. A Condição pós-moderna. Rio de Janeiro: J. Olympio, 1998.

MATTELART, A.; MATTELART, M.; PICCINI, M. Los medios de comunicación de masas: la ideología de la prensa liberal. Santiago de Chile: Cuadernos de la Realidad Nacional, 1970.

MATtelart, A; DORfMAN, A. Para ler o Pato Donald. São Paulo: Paz e terra, 2010.

MILLER, K. Communication theories: perspectives, processes, and contexts. New York: McGraw-Hill, 2002.

MOGENDORFF, J. R. A Escola de Frankfurt e seu legado, Verso e reverso, v. XXVI, n. 63, p. 152-159, 2012.

MORIN, E. Os sete saberes necessários à educação do futuro. São Paulo: Cortez, 2005.

MOTTA, L. G. Cultura de resistência e comunicação alternativa no Brasil. In: Comunicação\&Política, v. 1, n. 1, 1983.

MOTTA, L. G. A pesquisa em jornalismo no Brasil: paradigmas em confronto. In: LOPES, M. I.; MELO, J. M. V.; MOREIRA, S. V.; BRAGANÇA, A. Pensamento comunicacional brasileiro. São Paulo: INTERCOM, 2005.

NICOLESCU, B. Manifesto da transdisciplinaridade. São Paulo: TRION, 1999.

RUDIGER, F. Comunicação e indústria cultura: a fortuna da teoria crítica nos estudos de mídia brasileiros. Revista Brasileira de Ciências da comunicação, v. 21 , n. 2, p. 13-25, 1998.

SEN, A. Desenvolvimento como liberdade. São Paulo: Cia das Letras, 2009. SOUSA SANTOS, B. Introdução a uma ciência pós-moderna. Rio de Janeiro: Graal, 1989.

THIOLLENT, M. Crítica metodológica, investigação social e enquete operária. São Paulo: Polis, 1980.

THOMPSOM, E. P. The making of the English working class. UK: Penguin, 1988.

UNESCO. Um solo mundo, voces multiples - Informe de la comisión internacional sobre problemas de la comunicación. México/UNESCO, Paris: Fondo de Cultura Económica, 1980.

VERÓN, E. Lenguaje y Comunicación Social. Buenos Aires: Ed. Nueva Visión, 1969.

WEBER, M. H.; BENTZ, I.; HOHLFELDT, A. Tensões e objetos da pesquisa em comunicação. Porto Alegre: Sulina, 2002. 
WEIL, P. Holística: uma nova visão e abordagem do real. São Paulo: Palas Atenas, 1990.

WILLIAMS, R. Cultura - sociología de la comunicación del arte. Buenos Aires:

Paidós, 1981.

Luiz G. Motta Full professor at the University of Brasília ("UnB") and a registered researcher in the National Council for Scientific and Technological Development ("CNPq"), with a doctorate from the University of Wisconsin and a postdoctoral internship held at the Universidad Autónoma de Barcelona. E-mail: luizmottaunb@yahoo.com.br 